\title{
THE EL PALTO PHASE OF NORTHERN PERÚ: CULTURAL DIVERSITY IN THE LATE PLEISTOCENE-EARLY HOLOCENE*
}

\author{
LA FASE EL PALTO EN EL NORTE DE PERÚ: DIVERSIDAD CULTURAL \\ EN EL PLEISTOCENO TARDÍO-HOLOCENO TEMPRANO
}

\author{
Greg J. Maggard ${ }^{1}$
}

\begin{abstract}
On Perú's North Coast, the earliest documented lithic traditions are collectively known as the El Palto Phase ( 14,200-9,600 cal BP). This phase, which spans the Late Pleistocene to Early Holocene, contains evidence for several contemporary or overlapping traditions, including early unifacial assemblages, and the Fishtail and Paiján complexes. Recent study of El Palto phase sites in the lower Jequetepeque Valley focused on evaluating the relationships between these assemblages and the populations who manufactured them. The results from several long-term regional studies are considered with these analyses to provide a new synthesis regarding early settlement patterns and technological change in this region of the Central Andes.
\end{abstract}

Key words: Late Pleistocene, Early Holocene, colonization, El Palto phase, lithic technology, settlement patterns.

En la costa norte del Perú, las tradiciones líticas más tempranas documentadas se conocen, en conjunto, como la fase El Palto ( 14.200-9.600 cal a.p.). Esta fase, que abarca desde el Pleistoceno Tardío hasta el Holoceno Temprano, contiene evidencias de varias tradiciones contemporáneas o que coinciden parcialmente en el tiempo, lo que incluye conjuntos unifaciales tempranos y los complejos Cola de Pescado y Paiján. Un reciente estudio de los sitios de la fase El Palto en el valle bajo de Jequetepeque se enfocó en la evaluación de los vínculos entre estos conjuntos y las poblaciones que los produjeron. Los resultados de varios estudios regionales de largo plazo se combinan con estos análisis con el objeto de proporcionar una nueva síntesis acerca de los patrones de asentamiento temprano y el cambio tecnológico en esta región de los Andes Centrales.

Palabras claves: Pleistoceno Tardio, Holoceno Temprano, colonización, fase El Palto, tecnología lítica, patrones de asentamiento.

The Central Andes contains one of the best documented records of initial human migration and early settlement in the New World. The archaeological signatures of these broad processes span the Late Pleistocene to Early Holocene periods and are indicative of substantial regional variability in terms of technological and economic patterns (Borrero 2006; Bryan 1991; Dillehay 2008; Dillehay and Kaulicke 2013; Lavallée 2000; Miotti 2003). In Northern Perú, Late Pleistocene to Early Holocene age sites have been collectively referred to as the El Palto phase (ca. 14,200-9,600 cal BP) (Maggard and Dillehay 2011). The majority of El Palto phase sites have been identified in the Zaña (Dillehay 2000; Rossen 1991), Jequetepeque (Dillehay et al. 2003; Maggard and Dillehay 2011), Chicama (Becerra
2000; Briceño 2004; Chauchat et al. 2006; Gálvez 2004), and Moche Valleys of northern coastal Perú (Briceño 2013; Ossa and Moseley 1972; Uceda 1992) (Figure 1). A few El Palto phase sites have also been documented in other parts of the northern Perú (León et al. 2004; Richardson 1981; Malpass 1983).

Among El Palto phase sites, a range of variability in technological strategies has been long recognized (Becerra 2000; Chauchat et al. 2004; Gálvez 2004). However, the timing, scale, and significance of this variability has remained relatively poorly understood, although it is clear that that the El Palto phase was characterized by several distinct -yet contemporary or overlapping- technological traditions that include the Early Unifacial, Fishtail,

\footnotetext{
* This article was originally presented at the "Early Lithic Technologies: Beyond Regional Projectile Point Typologies" Symposium at the 77th SAA Meeting Memphis, Tennessee, April 2012. Guest editors Kurt Rademaker and César Méndez conducted the peer-review process following the Journal's editing policies.

1 Kentucky Archaeological Survey, University of Kentucky, 1020A Export Street, Lexington, KY 40506 U.S.A. gjmagg2@uky.edu
} 


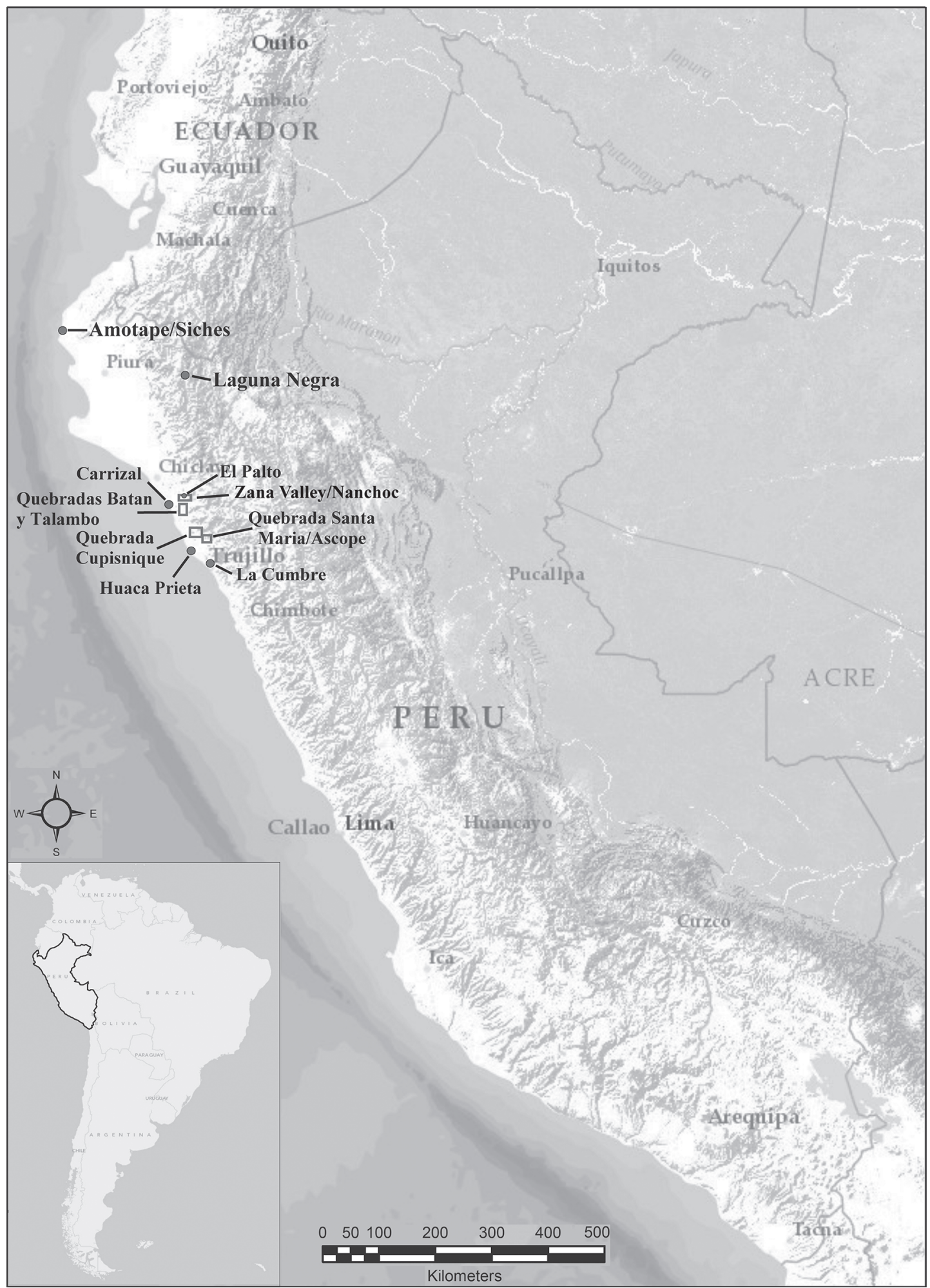

Figure 1. Map of the north coast of Perú with El Palto phase projects and sites discussed in the text (map generated with ArcMap 10.1 by the author).

Mapa de ubicación de proyectos y los sitios de la fase El Palto tratados en el texto (elaboración del mapa, por medio del programa ArcMap 10.1: Greg Maggard). 
and Paiján. Recent analysis of $126 \mathrm{El}$ Palto phase sites in the Quebradas del Batán and Talambo (QBT) of the lower Jequeptepeque Valley has resulted in a clearer picture of the landscape use and settlement organization, economic practices, and technological strategies that characterize the different early traditions (Figure 2) (Maggard 2010a; Maggard and Dillehay 2011). These results are also informing a new understanding of the staggered nature of regional colonization and the development of localized economic strategies. This article presents a summary of the El Palto phase technological, economic, and settlement data from the QBT and other regions of the Peruvian north coast.

\section{Paleoenvironment and Landscape of Northern Perú}

In general, the north coast of Perú is a complex environmental setting consisting of three broad macrozones: Pacific Ocean, coastal plain, Andes Mountains. These broad physiographic zones are characterized by a diversity of localized ecological settings that include river valleys, estuaries, tidal zones, springs, quebradas, pampas, lomas, subtropical dry and humid forests, and other low- and high-montane zones (Craig 1985; Moseley 1992; ONERN 1976; Pulgar Vidal 1996; Tosi 1960). El Palto phase sites have been identified in a diverse array of settings that include coastal (Dillehay et al. 2012; Richardson 1981), coastal plain (Chauchat et al. 2006), and the low Andean foothills and quebradas (Dillehay and Maggard 2011; Gálvez 2004; Maggard 2010a).

Paleoenvironmental proxy data suggest that throughout Andean South America, Late Pleistocene to early Holocene paleoclimates were highly variable from region to region and fluctuated over time (Bromley et al. 2009; Denton et al. 1999; Gosling et al. 2008; Hajdas et al. 2003; Haselton et al. 2002; Hillyer et al. 2009; Mayle et al. 2009; Thouret et al. 1996; Vimeux 2009). In northern Perú, fluctuations in temperature are believed to have alternatively lowered and raised tree-lines, altered biogeographic distributions, and produced mixed associations (Bush 2002; Hillyer et al. 2009; Netherley 2011; Weng et al. 2006). The intensity of these effects during cold reversals (like the Younger Dryas) also influenced precipitation levels and available moisture (Bromley et al. 2011; Gosling et al. 2008; Vimeux 2009; Weng et al. 2006). These alternating pressures had differential impacts on the distributions of specific plant and animal species within different ecological settings (Bush 2002; Mayle et al 2009). Along the coast, eustatic sea level change and fluctuations in sea surface temperatures (SST) also likely produced dramatic effects on resource distributions and availability (Ortleib 2000; Rein et al. 2005; Sandweiss 2003).

The impacts of these regional-scale pressures are not as well understood at the local-level. Some areas, like the low quebradas systems of the Jeqeutepeque and Zaña Valleys in northern Perú appear to have witness somewhat less variability in environmental conditions than locations on the coast or at higher elevations (Netherley 2011:6776). The lower portions of the quebrada systems were included in the broad bands of seasonally dry forest associations that existed along the margins of the coastal plain and along the Andean flanks. At higher elevations, the quebradas provided access to humid montane forest associations (Dillon 1994; Dillon et al. 1995). Seasonal dry forests were more open than humid forests and provided a relative abundance of potential plant and animal resources (Mares 1992; Netherly 2011; Piperno and Pearsall 1998). Netherly (2011:66) has argued that during the Pleistocene-Holocene transition, seasonal forests were the most extensive biogeographic formation along the western Andean flanks, and stretched from western Colombia to northern Perú.

It is not coincidental that the vast majority of El Palto phase sites, particularly the terrestrially-oriented Fishtail and Paiján, are found in areas that would have been located within the dry forest association and suggest that this environmental formation played a significant role in the migration and settlement of the north coast region. Understanding the prevailing environmental conditions of the Late PleistoceneEarly Holocene provides us with an opportunity to better contextualize the relative diversity of early traditions that have been identified in northern Perú. For the El Palto phase, differing responses to these environmental conditions and pressures are manifest in the variety of technological strategies pursued and the patterns of settlement organization and landscape use (Maggard 2010a; Maggard and Dillehay 2011).

\section{El Palto Phase Early Unifacial Traditions}

El Palto phase lithic traditions on the Peruvian north coast include early unifaces, along with the 


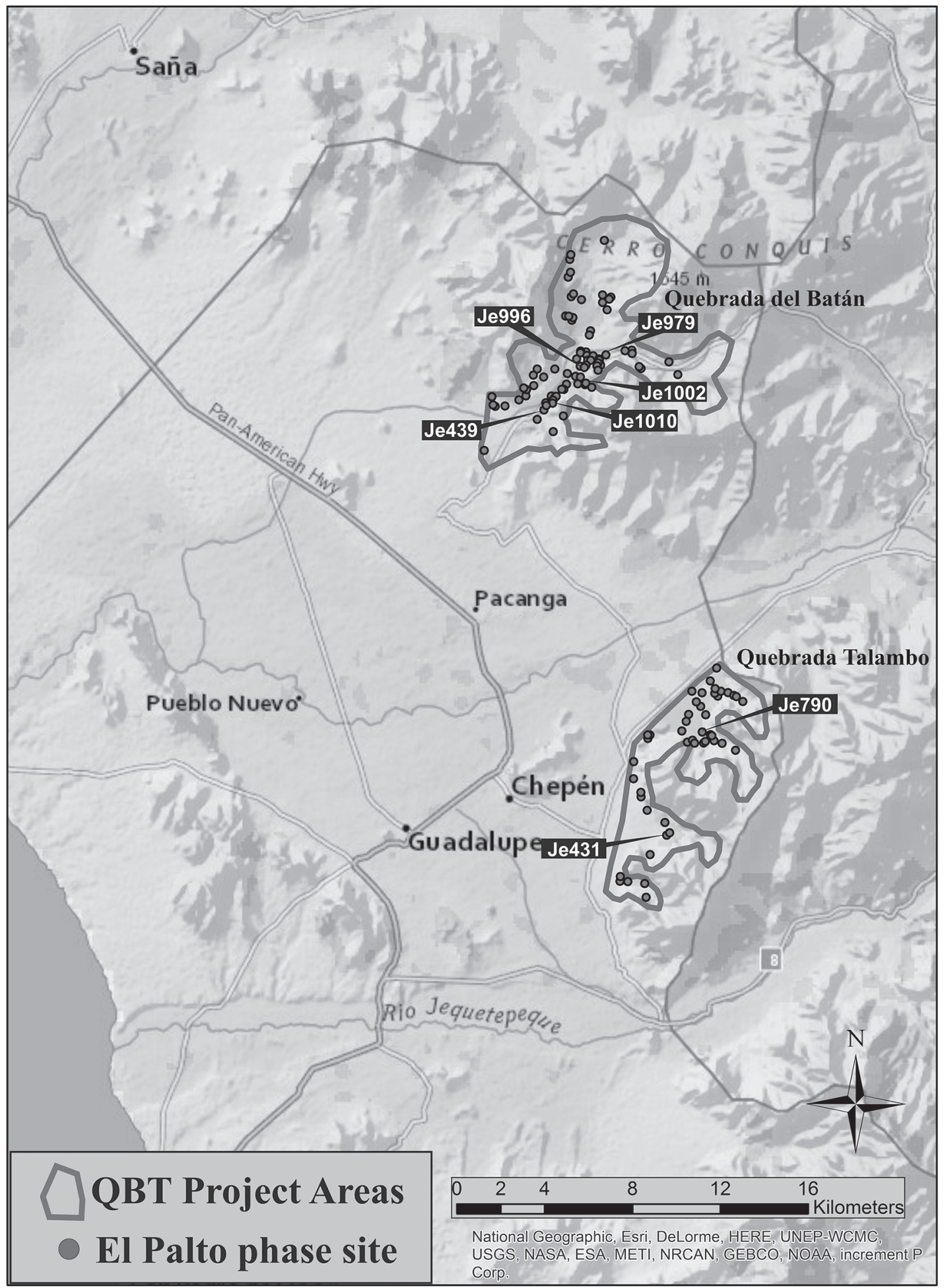

Figure 2. El Palto phase sites in the Quebradas del Batán and Talambo (QBT) project area (map generated with ArcMap 10.1 by the author).

Sitios de la fase El Palto ubicados en el área del Proyecto Quebradas del Batán y Talambo (elaboración del mapa, por medio del programa ArcMap 10.1: Greg Maggard). 
more widely known Fishtail and Paiján bifacial traditions. Early Unifacial traditions are the least well understood, but have been documented at several locations including the Amotape/Siches sites near Talara (Richardson 1981, 1973), Huaca Prieta in the Chicama Valley (Dillehay et al. 2012), and several sites in both the Carrizal delta and Nanchoc region of the Zaña Valley (Dillehay 2000; Maggard and Dillehay 2011). In the Sechura desert of northern Perú, Richardson $(1981,1973)$ identified several Early Unifacial sites -referred to as the Amotape complex- situated on uplifted sections of Pleistocene coast. Lithic artifacts from the Amotape sites consist of flakes, flake denticulates, and pebble-cores manufactured from local quartzites and chalcedonies (Richardson 1973). The Amotape complex dates to between 13,300-9,000 cal BP and has been interpreted as representing a generalized foraging economy that emphasized the exploitation of nearby mangrove and estuarine resources.

Early Unifacial lithics from the Zaña Valley have been identified by Dillehay and others (Dillehay 2000; Maggard and Dillehay 2011) in both buried and surface contexts. The El Palto site - which gives this phase its name- is a multicomponent site in the upper Zaña. The deepest layers (ca. 1-1.6 m below surface) contained flakes and core tools manufactured from local quartzite, rhyolite, and basalt that were associated with several thin charcoal lenses. The basal layer has been radiocarbon dated to $13,859-13,178$ cal BP (Maggard and Dillehay 2011). Farther down the valley, several small sites have also been identified on remnant Pleistocene surfaces along an abandoned paleo-channel of the Zaña River. The lithics from these sites consist of flakes and edge-trimmed unifacial tools that display a heavy desert varnish from long exposure to wind and solar radiation. No radiocarbon dates have been collected from these sites, but the landform age is suggestive a possible range of $12,500-10,000 \mathrm{cal}$ BP (Dillehay 2000).

Recent excavations by Dillehay (Dillehay et al. 2012) at the large and complex site of Huaca Prieta in Chicama Valley identified several edgetrimmed unifacial tools and flakes from very deeply buried, sub-mound contexts containing thin lenses of ash and charcoal. Huaca Prieta is located on a Pleistocene coastal terrace and the buried, intact contexts have been extensively dated to between 14,200-13,300 cal BP (Dillehay et al. 2012). The associated unifacial tools are manufactured from locally available basalt and quartzite cobbles and were recovered with a wide range of marine fauna and shellfish, suggesting a maritime economic focus.

The Early Unifacial lithics recovered from multiple sites across the north coast are highly similar in terms of morphology and the reliance on locally-available raw material resources. Although relatively few in number, the estuarine or near-coast location of several of these sites (e.g., Huaca Prieta, Talara, and Carrizal delta sites) is distinct from the Fishtail and Paiján pattern of settlement within interior quebrada systems. The coastal orientation of the Early Unifacial sites and documented exploitation of marine resources are suggestive of early maritime/coastal economies, but likely also included the use of interior locations and terrestrial resources-either through direct acquisition or trade. Although similar Early Unifacial assemblages have been documented at the Las Vegas site in Ecuador (Stothert and Sánchez 2013; Stothert et al. 2003) and at several coastal locations in southern Perú (deFrance et al. 2001; Sandweiss et al. 1998), we do not yet understand how these sites may have been related or if they represent similar social groups.

Because the Early Unifacial traditions represent the earliest documented human occupation of the north coast (ca. 14,200-13,000 cal BP) and appear to have pursued maritime/coastal economies, it is likely that these groups colonized the region via a coastal route. If this is the case, additional sites may be located on uplifted sections of Pleistocene coastlines or in buried settings. As we begin to understand the sequence and distribution of these sites across the western coast of South America, we will be able to better address other important questions related to the timing of the coastal migration and how the different sites containing early unifacial materials may be related to one another or later inland occupations.

\section{El Palto Phase Bifacial Traditions}

In addition to the Early Unifacial lithic materials, at least two bifacial traditions -the Fishtail and Paiján- have been documented on the north coast. Although the Fishtail and Paiján complexes both contain a range of bifacial, unifacial, and flake tools, they are primarily known for their distinctive point styles (Briceño 2004; Chauchat et al. 2004). At present, it remains unclear how the Fishtail and Paiján may be related to other early bifacial traditions 
that have been documented in the highlands and southern coastal Perú (Aldenderfer 1998; deFrance et al. 2001; Kaulicke 2000; Lavallée 2003; Rick and Moore 2000; Sandweiss and Rademaker 2013).

\section{Fishtail Complex}

The Fishtail "type" shows considerable variability in form across its known distribution from the southern cone of South America to Central America (Bell 2000; Briceño 2000; Castiñeira et al. 2012; Flegenheimer et al. 2003; Nami 2007; Politis 1991; Suárez and López 2003). Thin and wide stemmed, pronounced and rounded shoulders, fluted and unfluted varieties have been documented and are all typically subsumed within the general 'Fishtail' label. At present, we do not know if this variability may represent distinct types of Fishtail points or geographic variation (Castiñeira et al. 2012; Suárez 2006, 2003). As the few points recovered from the QBT sites demonstrate, this is equally true in northern Perú (Figure 3).

In northern Perú, the Fishtail complex is considered representative of the early El Palto phase and appears to temporally overlap with the both the Early Unifacial tradition and the Early Paiján (Maggard 2010a; Maggard and Dillehay 2011). Although it is best known from numerous sites identified in the Southern Cone of South America, a few sites containing Fishtail points have been documented in the Central Andes. Among these sites are El Inga in Ecuador (Bell 2000; Mayer-Oakes 1986), La Cumbre in the Moche Valley (Ossa 1976), Laguna Negra in northern Perú (León et al. 2004), two sites in the Quebrada Santa Maria in the Chicama Valley (Briceño 2004, 2000) and four sites (Je979, 996, 1002, and 1010) in the Quebrada del Batán of the lower Jequetepeque Valley (Maggard 2010b).

The four Quebrada Batán Fishtail site are openair settings situated on alluvial terraces bordering dry drainages that provide commanding views of the surrounding landscape and coastal plain (Figure 4). Like the sites in the Chicama and Moche valleys, each of the Quebrada Batán Fishtail sites also contained Paiján points (Briceño 2004; Ossa 1976). Both the Paiján and Fishtail points were recovered from deflated surface contexts, along with a variety of unifaces, bifaces, and retouched flakes. The few Fishtail sites in the QBT region are characterized by small, light density lithic scatters and are suggestive of relatively ephemeral and redundant use of the landscape. Excavations conducted at two sites (Je 996 and 1002) yielded low densities of cultural materials in the levels associated with Fishtail occupations, primarily consisting of lithic debitage and retouched and utilized flakes (Maggard 2010a). No features or dense midden were associated with the Fishtail occupations and in general, the deposits are suggestive of relatively short-term occupations.

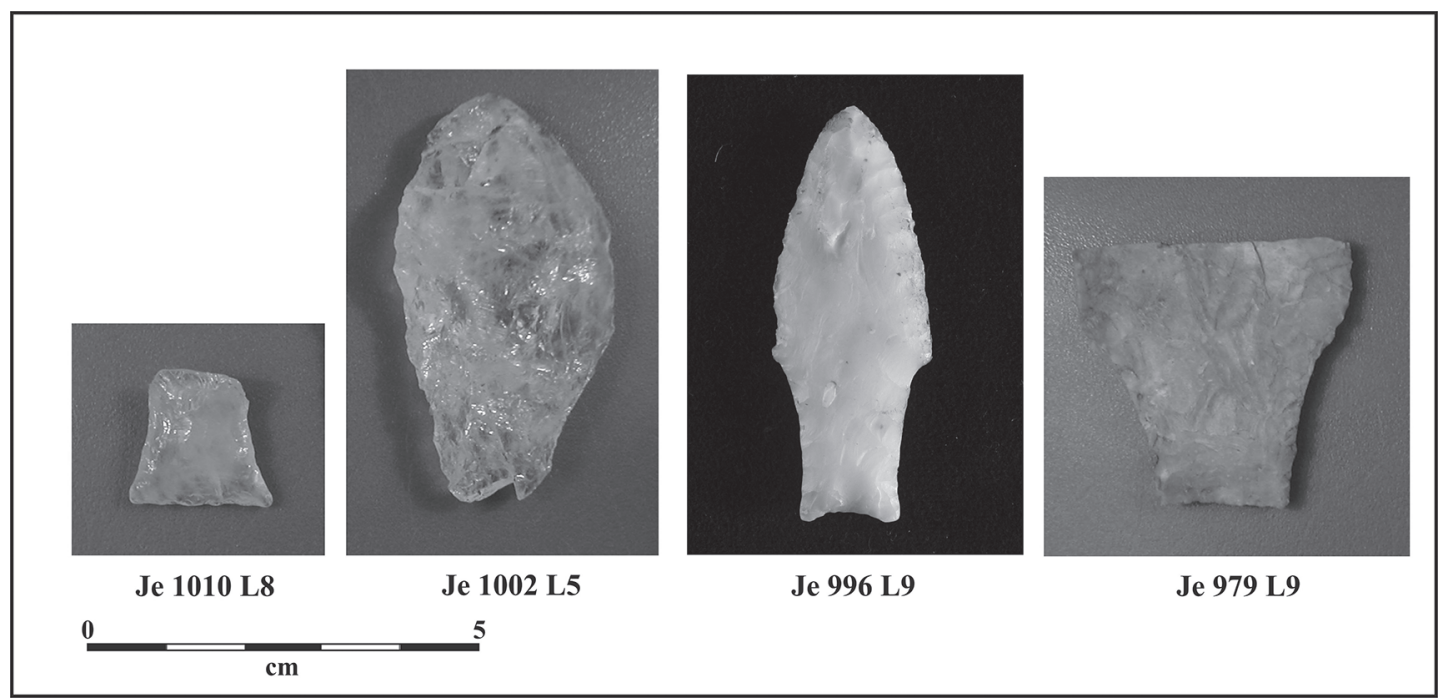

Figure 3. Fishtail projectile points recovered in the Quebradas del Batán and Talambo (photos: Greg Maggard).

Ejemplares de puntas de proyectil en Cola de Pescado procedentes del área del Proyecto Quebradas del Batán y Talambo (fotos: Greg Maggard). 


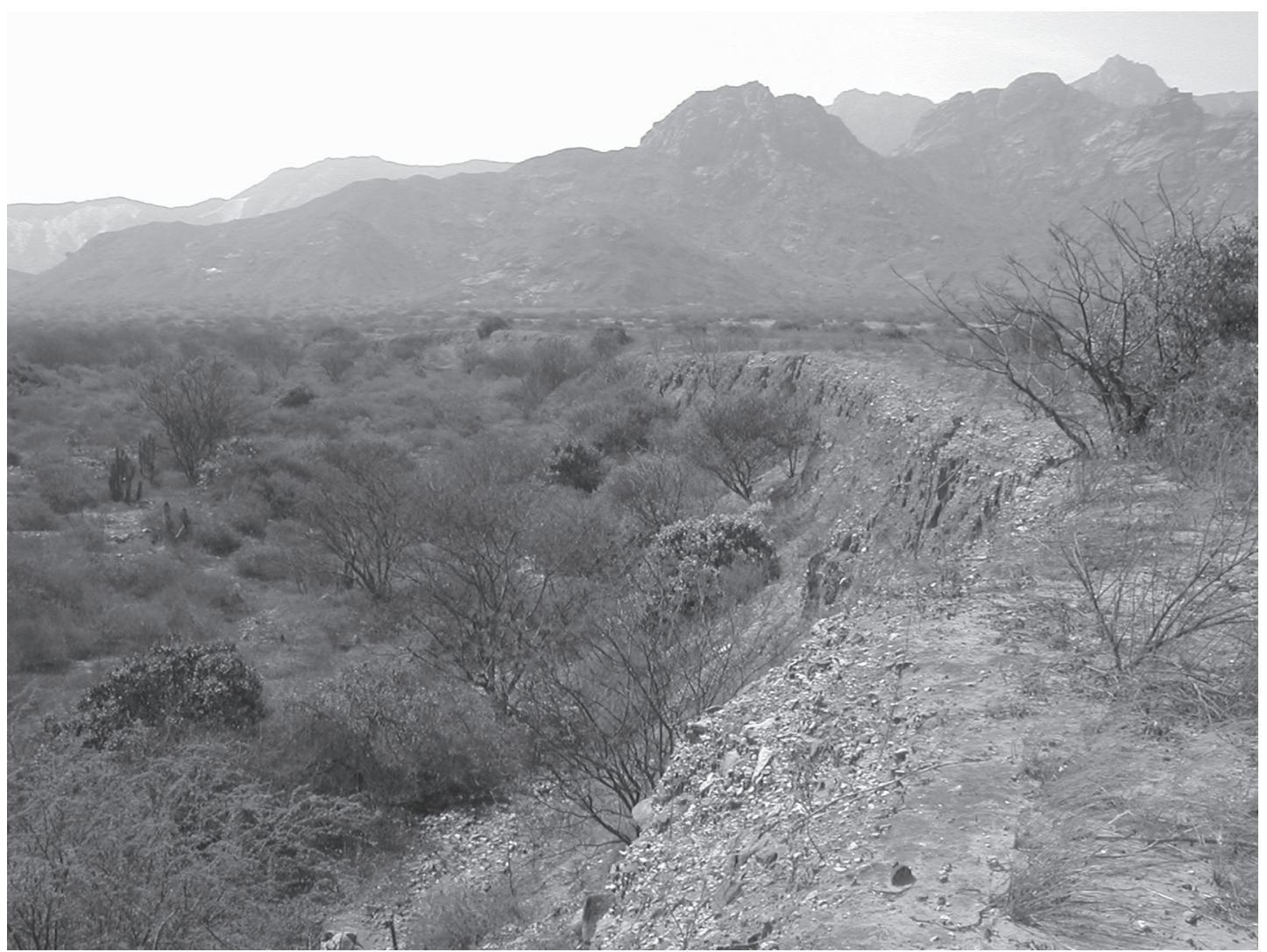

Figure 4. Site Je 996 in the Quebrada del Batán (photo: Greg Maggard).

Sitio Je 996, situado en la Quebrada del Batán (foto: Greg Maggard).

Only a limited amount of faunal material was recovered from the Fishtail levels at sites Je 996 and 1002. The few identifiable specimens included Pseudalopex sp. (South American fox), Lacertilia (lizard), Decapoda (crab claw fragment), and Rajiformes (rays and skates). Interestingly, these species are suggestive of exploitation of both terrestrial and marine/coastal resources. Lithic raw materials are dominated by non-local stone resources -particularly cherts and chalcedonies from the neighboring highlands- although local quartz crystal was also used.

When considered with the other sites documented in the north coast, the data from the four QBT Fishtail sites are suggestive of a regional settlement pattern that likely involved only short-term use of a given location. Fishtail groups probably relocated relatively frequently between short-term camps. Subsistence information is limited, but suggests a relatively large foraging range that likely included portions of the coast, interior, and highlands. The frequent presence of non-local raw materials used in the manufacture of Fishtail lithic tools, combined with the presence of a few Fishtail sites in upland settings (León et al. 2004), is minimally suggestive of relatively long distance forays to the Andean highlands. Although the bulk of Fishtail sites have been found in the lower Andean foothills, the emerging pattern is one of relatively high mobility and seasonal transhumance across vertically distributed ecological zones (including the coast, dry forest, humid forest, and possibly the paramo), which is similar to the pattern suggested for Fishtail and other early sites in southern Perú (Aldenderfer 1998; Sandweiss and Rademaker 2013).

Fishtail points from South America generally date to ca. 13,300-11,300 cal BP (Borerro 2006; Dillehay 2000; Nami 2007). AMS dates from two of the sites in the Quebrada Batán (Je 996 [12,822$12,413 \mathrm{cal} \mathrm{BP}]$ and 1002 [13,073-12,860 cal BP]) correspond well with the continental dates, but suggest a somewhat more restricted time frame 
of regional occupation (ca. 13,100-12,400 calBP) (Maggard 2010a). However, because so few Fishtail sites in northern Perú have been documented, much less excavated or dated, our understanding of Fishtail occupation in northern Perú remains relatively limited.

\section{Paiján Complex}

The Paiján complex is a relatively welldocumented archaeological phenomenon that has been dated to ca. 13,000-10,000 cal BP (Chauchat et al. 2006; Dillehay 2000), although in the QBT Paiján sites range between 12,800-9,600 cal BP (Maggard 2010a). Numerous Paiján sites have been documented across the north coast-primarily between the Zaña and Casma Valleys. Paiján sites are typically located within or near the margins of the large quebrada systems that dissect the western Andean foothills, some 25-35 km east of the Pacific coast and 200-600 $\mathrm{m}$ asl (Figure 5) (Dillehay et al.
2003; Maggard 2010a; Maggard and Dillehay 2011). A few Paiján sites have also been identified on the coast and coastal plain (Chauchat et al. 2006; Malpass 1983) and at higher elevations (ca. 800$1600 \mathrm{~m}$ asl) (Briceño 2013).

In comparison to Fishtail points, Paiján points have a restricted geographic distribution and have been the subject of several regional-scale analyses (Becerra 2000; Chauchat et al. 2006; Chauchat et al. 2004; Malpass 1983; Ossa 1973; Uceda 1992). The presence of several different varieties of Paiján points has been previously recognized (Gálvez 2004; Malpass 1983). However, these varieties have generally been subsumed within the larger descriptive of 'Paiján'. As a result, the Paiján "type" has come to include virtually all stemmed projectile points on the north coast that cannot be clearly attributed to another type (e.g., Fishtail, Laurel-leaf, or various highland types). This lack of understanding in the variability of projectile point form has limited the identification of temporal, economic, and settlement

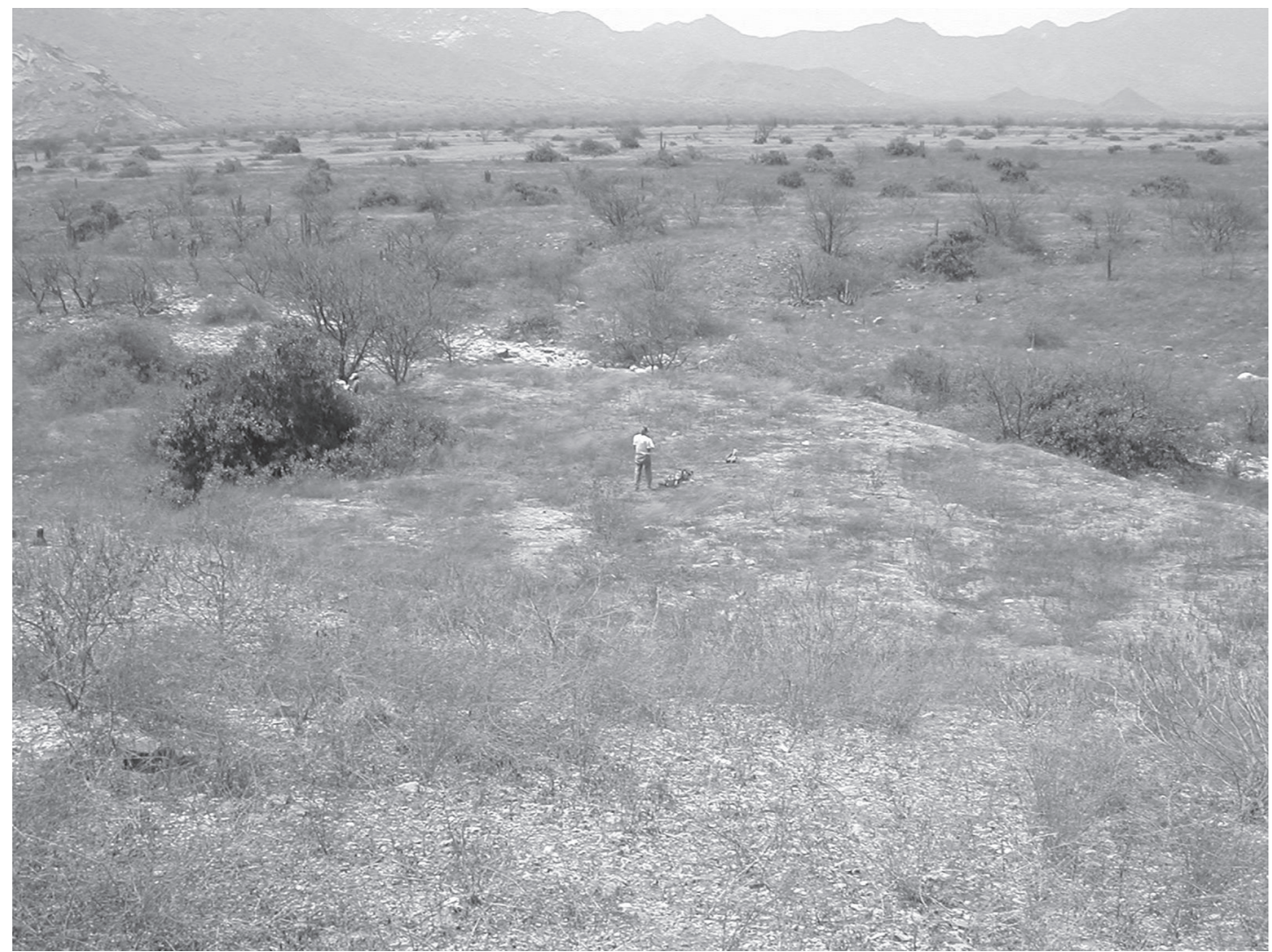

Figure 5. View to the north from Paiján site Je 984 (foreground) (photo: Greg Maggard).

Vista al norte desde el sitio Paiján Je 984 (primer plano) (foto: Greg Maggard). 
changes within the broad Paiján complex, as well as our understanding of interaction between neighboring coastal and highland populations.

Paiján settlement on the north coast contrasts sharply with that of the Fishtail. Unlike Fishtail sites, which are represented only by short-term camps, Paiján sites are more numerous, encompass a range of types and functions, and are more widely spread across different kinds of landforms along the Andean flanks. Paiján sites in the QBT included basecamps, field camps, transitory stations, and quarries/workshops that appear to have had different functional roles within a more logistically-organized settlement system (Maggard 2010a).

One of the characteristic features of excavated Paiján sites is the similarity in use of a broad spectrum of subsistence resources. Combinations of various terrestrial mammals, lizards, birds, and terrestrial snails, along with several marine and freshwater resources (including several fish species) characterize the subsistence remains reported from sites across the north coast (Briceño 2000; Chauchat 1998; Chauchat et al. 2006; Dillehay et al. 2003; Gálvez 2004, 2000, 1992; Malpass 1983). Paiján sites excavated in the QBT yielded a similar diversity of faunal resources (Maggard 2010a). Paiján faunal materials recovered in the QBT encompassed a range of terrestrial mammals, including Cervidae (deer), Tayassuidae (peccary), Pseudalopex sp. (South American fox), Mustelidae (weasels, skunks, and otters), Sciurus sp. (tree squirrel), and Sigmodontinae (New World rats and mice). Reptiles (Teiidae [whiptails and tegus] and Dicrodon sp. [desert tegu]) and birds (Passeriformes [perching birds] and Columbidae [doves and pigeons]) were also recovered. Marine resources included Micropogonias sp. (croaker), Mugil sp. (mullet), Calamus brachysomus (probably Pacific porgy), Haemulidae (grunts), Ariidae (sea catfish), and Osteichthyes (indeterminate bony fish).

In addition to the faunal resources, plant resources were probably equally important components of Paiján subsistence (Dillehay and Rossen 2002; Piperno 2011; Piperno and Dillehay 2008). Direct evidence for plant use (i.e., carbonized floral remains, phytoliths, pollen) from Paiján contexts is rare, but can be inferred based on corollary evidence like the presence of groundstone tools (Dillehay and Rossen 2002; Stackelbeck 2008). Groundstone tools, including both manos and batanes, were identified at nine sites in the QBT and are suggestive of the importance of plant resources within the broad spectrum subsistence strategy of the Paiján. One site (Je 439) contained evidence of a specialized activity area where multiple manos and batanes were identified in close proximity to a Paiján structure (Figure 6) (Maggard 2010a).

Paiján resource use is indicative of a broad spectrum pattern and basecamps were likely intentionally situated to provide access to a wide diversity of resources. The density of Paiján sites within the large quebrada systems of the western Andean foothills suggests that these areas were important in structuring Paiján settlement (Maggard and Dillehay 2011). As discussed previously, the paleoenvironment of the western Andean foothills was dominated by a dry forest association that incorporated varied potential plant and animal resources. The quebrada systems act as natural corridors into the low Andean flanks and likely provided the easiest access to desired resources and locations.

The density of Paiján settlement along the western Andean flanks (Chauchat et al. 2006; Maggard and Dillehay 2011) suggests that the seasonal movement of basecamps may have occurred in a linear fashion within the dry forest belt (Netherly 2011). A linear or back-and-forth pattern of movement between quebrada systems located in the dry forest belt is distinct from the transhumant pattern of the Fishtail, which emphasized vertical mobility across different ecological zones. Although the Paiján appear to have predominantly focused their movement along the Andean foothills in a logistical manner, this strategy also included forays to the coast and humid forests of the highlands (Briceño 2013).

As noted previously, a wide range of morphological variability has largely been subsumed within term 'Paiján'. Analysis of Paiján lithic assemblages from the QBT resulted in the identification of four distinct types of stemmed points that exist within the broader Paiján "type" and correspond to early and late subphases of the Paiján complex (Maggard 2010a). The recognition of these different stemmed point types indicates that the Paiján, rather than an single cultural phenomenon, is more likely a complex set of interrelated cultural expressions that reflect the economic and technological changes that occurred during the Pleistocene-Holocene transition (Maggard 2010a). The toolkit of the Paiján complex, as a whole, reflects broad-spectrum resource use and contains 


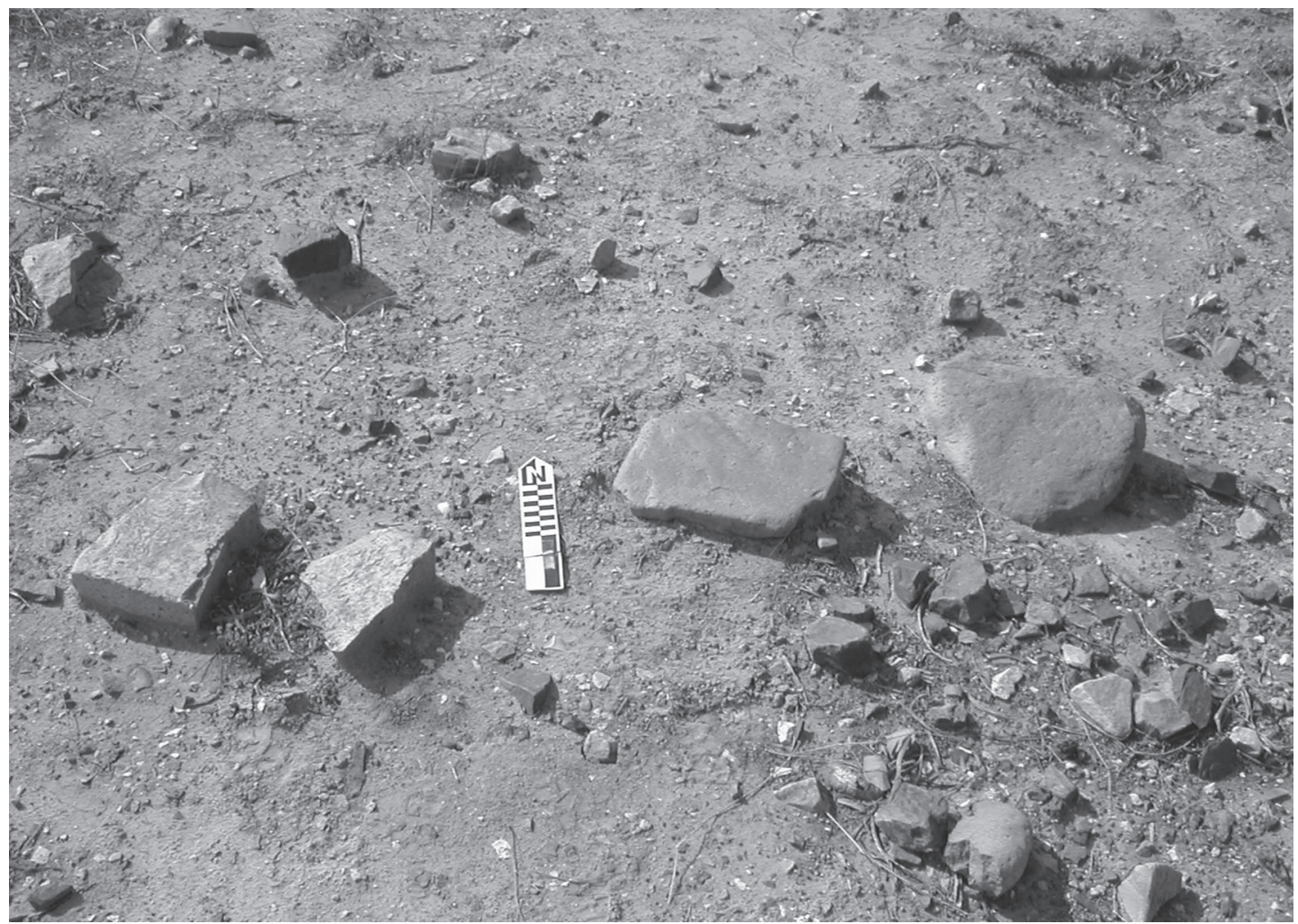

Figure 6. Activity area with grinding stones and batanes at Site Je 439 in the Quebrada del Batán (photo: Greg Maggard). Área de actividad con piedras del moler y batanes en el sitio Je 439 (foto: Greg Maggard).

a wide range of individual tool types including limaces, formal unifacial forms, retouched flakes, and groundstone-as well as the distinctive stemmed, bifacial projectile points (Figure 7).

The Classic Paiján type is diagnostic of the Early Paiján subphase and ranges in age from 12,800-11,200 calBP based on associated AMS dates from excavation (Figure 8) (Maggard 2010a). Local raw materials were overwhelmingly used in the manufacture of Classic Paiján points, which stands in contrast to the contemporary Fishtail points that frequently made use of non-local materials. The remaining three types (Talambo, Contracting Narrow stem, and Contracting Broad stem) are all believed to range in age between 11,200-9,600 cal BP based on associated dates and are representative of the Late Paiján subphase (Figure 9). These types are neither as internally consistent nor as long-lasting as the earlier Classic Paiján type, but display a similar heavy reliance on locally available raw materials.

At present, the technological relationships between the Early and Late Paiján types remain unclear. The contemporaneous presence of distinct
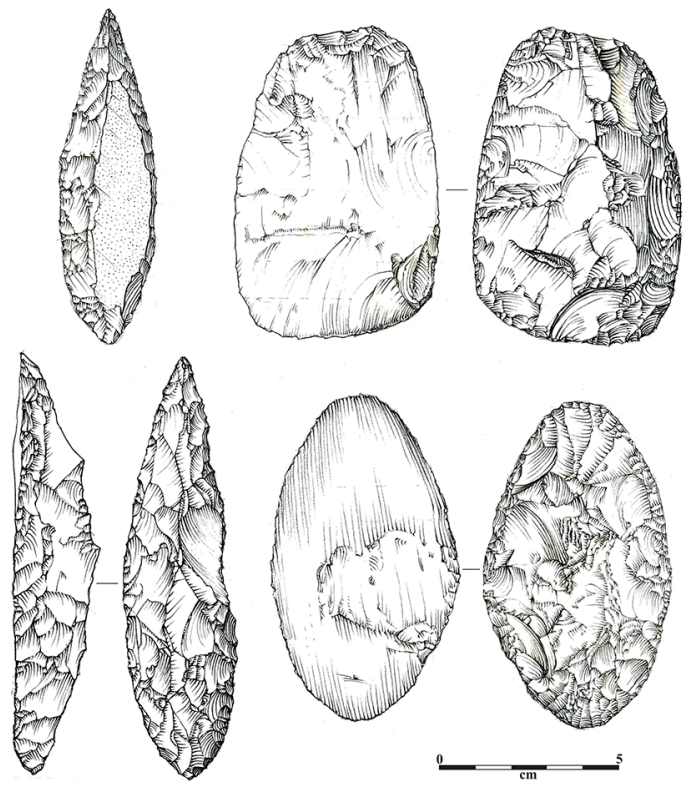

Figure 7. Examples of Paiján unifacial lithic tools from the Quebradas del Batán and Talambo (Illustrations: Iris Bracamonte). Ejemplares de los implementos líticos unifaciales de Paiján procendentes del área del Proyecto Quebradas del Batán y Talambo (elaboración de los dibujos: Iris Bracamonte). 


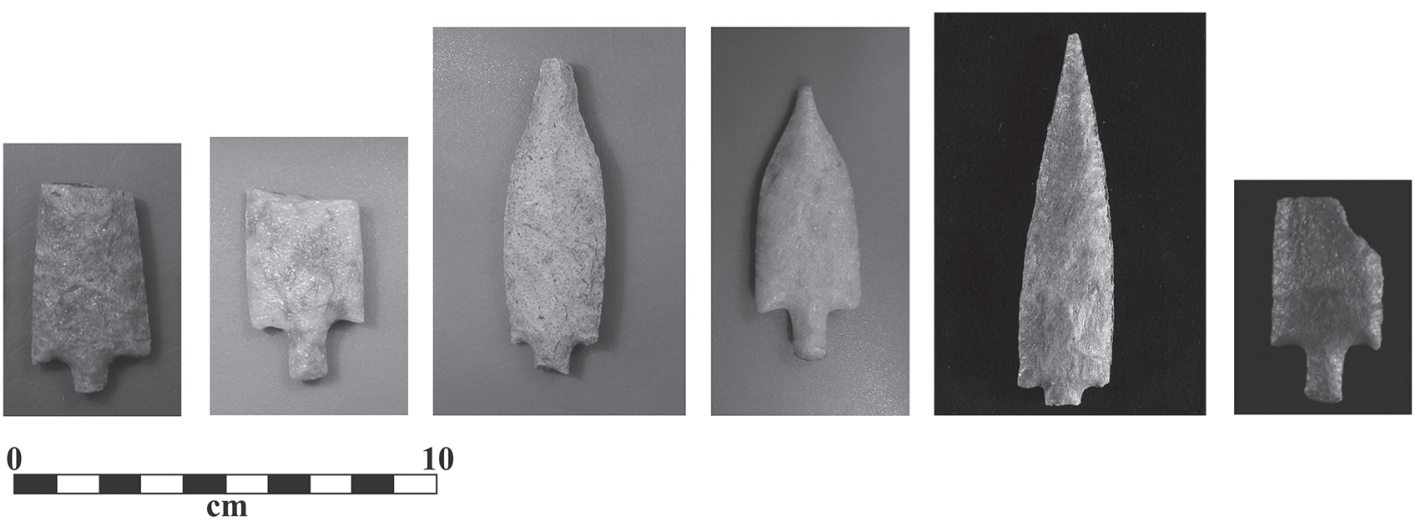

Figure 8. Examples of Early Paiján points from the Quebradas del Batán and Talambo (photo: Greg Maggard).

Ejemplares de puntas Paiján Temprano procedentes del área del Proyecto Quebradas del Batán y Talambo (fotos: Greg Maggard).

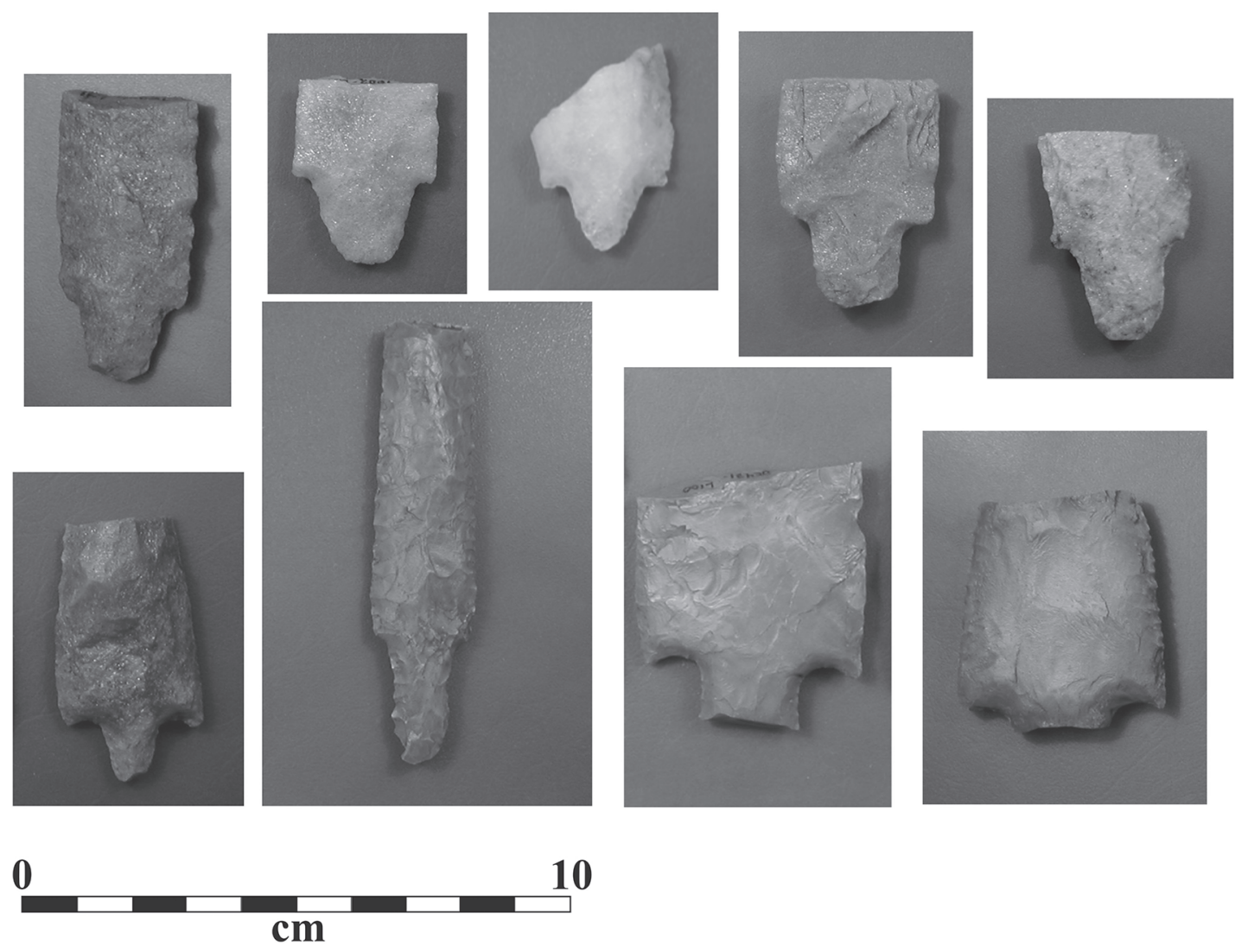

Figure 9. Examples of Late Paiján points from the Quebradas del Batán and Talambo (photo: Greg Maggard).

Ejemplares de puntas Paiján Tardio procedentes del área del Proyecto Quebradas del Batán y Talambo (fotos: Greg Maggard).

types after ca, 11,200 cal BP is suggestive of increasing specialization in design requirements over time that may be related to changing functionality of the tools. It is likely that some point forms represent projectiles, while others were intended to function as knives or butchery tools. Analysis of the QBT assemblages further suggests that there is a gradual shift in frequency of the kinds of tools associated with Early and Late Paiján points -particularly an increase in the frequency of unifacial and flake tools- which is suggestive of changing technological organization over time. 


\section{Early and Late Paiján}

The preceding discussions have described the general characteristics of the Paiján complex settlement, subsistence, and technological organization. Although it is often broadly conceptualized, the Paiján complex encompasses two sub-periods (Early and Late) that display slightly different organizational patterns (Dillehay et al. 2003; Maggard 2010a). In a general sense, the settlement and subsistence pattern is similar during both the Early and Late Paiján periods in that there is a continued emphasis on broad spectrum resource use. However, subtle changes in the number of sites and frequency of different types of sites are suggested between the Early and Late Paiján periods. Based on the QBT assemblage, there is a clear increase in the number of sites between the Early and Late periods, suggesting either an increase in population, more extensive use of the region, or both. Interestingly, the largest sites -which also contained dense midden deposits (Je 431 and 790)- are associated with Late Paiján occupations and seem to indicate a pattern of reducing mobility and longer occupations over time.

Several Paiján sites within the QBT contained small, stone-lined, domestic structures (Figure 10) (Dillehay 2013; Dillehay et al. 2003; Maggard 2010a). These stone-lined configurations represent the foundations for superstructures of perishable materials. They are generally circular in form, though others forms have been documented, including semi-lunar, 'L'-shaped, 'U'-shaped, and 'V'-shaped (Stackelbeck 2008). Paiján structures are typically found on larger sites that contain high densities of lithic materials-which were interpreted in the QBT as representing basecamps. Within the QBT, domestic structures are more frequent (and occur in larger numbers) on Late Paiján sites, suggesting that the Late Paiján probably had a lower anticipated mobility (sensu Kent 1991) than existed during the Early Paiján and likely occupied specific locations for longer periods of time. The increased frequency of expedient tools in Late Paiján assemblages coupled with the increased presence of domestic structures suggests that the reduction in mobility may have been related to a rising importance of plant resources over time (Dillehay et al. 2003; Maggard and Dillehay 2011).
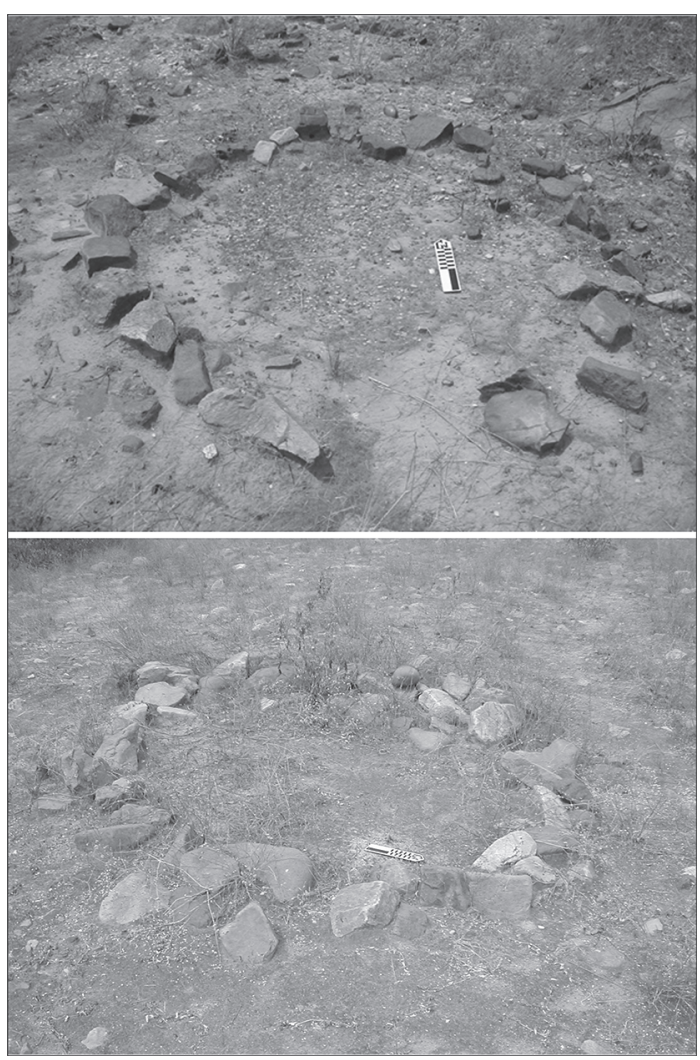

Figure 10. Examples of Paiján structure foundations from the Quebradas del Batán and Talambo: Je 980 (top), Je 861 (bottom) (photo: Greg Maggard).

Ejemplares de cimientos de unas estructuras Paiján documentado en el área del Proyecto Quebradas del Batán y Talambo: sitios Je 980 (cima) and Je 861 (fondo) (fotos: Greg Maggard).

Thus, subtle changes including the greater variability in projectile point form, increasing frequency of expedient tools, and an increased number and frequency of domestic structures point to reduced mobility and changing subsistence practices between the Early and Late Paiján periods. However, when compared to other El Palto complexes, such as the Fishtail complex or Early Unifacial tradition, the Early and Late Paiján have more in common -in terms of subsistence practices, technology, and settlement/mobility-than separates them. The importance of these subtle changes is that they represent the initiation of trends toward increased sedentism and early horticulture that are known to have appeared in the following Middle Preceramic period around ca. 9,500-8,500 cal BP (Dillehay et al. 2003; Piperno and Dillehay 2008; Rossen 2011; Stackelbeck 2008; Stackelbeck and Dillehay 2011). 


\section{Conclusion}

In sum, the earliest lithic traditions of the north coast of Perú represent several contemporary and overlapping complexes that include both unifacial and bifacial industries characterized by a diversity of settlement and subsistence practices. The earliest migrants into the north coast region probably entered the region via a coastal route sometime around ca. 15,000-14,000 cal BP. These groups maintained a unifacial technology apparently oriented to the exploitation of coastal and maritime resources. Interestingly, the earliest bifacial traditions do not appear in the north coast until nearly a millennia later (ca. 13,100 cal BP) and are indicative of more terrestrially-oriented economies. Because only a few Early Unifacial sites have been studied, the technological and social relationships between these and other early lithic industries remain unclear. It is important to note, however, that unifacial technology remains an important component of both the later Fishtail and Paiján complexes and characterizes virtually all the later Holocene-aged assemblages across the north coast.

The appearance of bifacial technology on the north coast after 13,100 cal BP is probably related to the development of new ecological zones during the last part of the Late Pleistocene period -specifically the seasonally dry and humid forests of the interior Andean foothills and quebrada systems- that fostered more widespread and intensive use of terrestrial resources. At present, there does not appear to be a descendant technological relationship between the Fishtail and Early Paiján. Rather, these two bifacial traditions appear to have co-existed in the north coast region. The situation is less clear among the various Late Paiján points, which share technological traits with both the Fishtail and Early Paiján. It is possible that Late Paiján lithic technology represents a regionalized 'settling in' process for both the Fishtail and Early Paiján during the Early Holocene period.

Additional research is needed to clarify not only the technological relationships between these early lithic traditions, but also to refine the chronology of the El Palto phase. Specifically needed are more intensive investigation of buried or relict Pleistocene landforms along the coast and additional survey and excavation of stratified sites in interior locations that have been protected from the persistent eolian deflation. As the number of documented early sites across the north coast increases, our understanding of the technological and subsistence relationships between the different early traditions will be greatly refined. Increasing our understanding will allow us to pose broader questions related to the changes in social and economic organization across the Pleistocene-Holocene transition and how those changes may have been interwoven in the processes of colonization and initial settlement in South America.

Acknowledgements: Funding for this research was provided by the National Science Foundation and the University of Kentucky. The Instituto Nacional de Cultura, Lima, Perú graciously provided permission to conduct the fieldwork. My special thanks are extended to César Méndez Melgar and Kurt Rademaker for inviting me to participate in the symposium and this volume. Thanks are also due to Tom Dillehay and Kary Stackelbeck for reading early drafts and to the two anonymous reviewers for their comments, which improved the manuscript. Any errors or omissions are the responsibility of the author alone.

\section{Referencias Citadas}

Aldenderfer, M. 1998. Montane Foragers: Asana and the SouthCentral Andean Archaic. University of Iowa Press, Iowa City.

Becerra Urteaga, R. 2000. Circulación y transformación de materias primas: el caso del paijanense en el valle de Chicama (11,000-7,000 a.p.). Boletín de Arqueologia PUCP 3 (1999):69-83.

Bell, R. 2000. Archaeological Investigation at the Site of El Inga, Ecuador. R. E. Bell Monographs in Anthropology no. 1, Sam Noble Oklahoma Museum of Natural History, University of Oklahoma. Norman, Oklahoma.

Borrero, L. 2006. Paleoindians without mammoths and archaeologists without projectile points? The archaeology of the first inhabitants of the Americas. In Paleoindian Archaeology: A Hemishperic Perspecitive, edited by J. Morrow, and C. Gnecco, pp. 9-20. University Press of Florida, Gainesville.

Briceño Rosario, J. 2000. Quebrada Santa Maria: las puntas en cola de pescado y la antigüedad del hombre en Sudamerica. Boletin de Arqueologia PUCP 3 (1999):19-39. Lima.

Briceño Rosario, J. 2004. Los primeros habitantes en los Andes centrales y la tradición de puntas de proyectil "cola de pescado" de la quebrada de Santa María. In Desarrollo Arqueológico Costa Norte del Perú, edited by L. Valle Alvarez, pp. 29-44. SIAN, Trujillo. 
Bromley, G., B. Hall, K. Rademaker, C. Todd, and A. Racoviteanu 2011. Late Pleistocene snowline fluctuations at Nevado Coropuna $\left(15^{\circ} \mathrm{S}\right)$, southern Peruvian Andes. Journal of Quaternary Science 26:305-317.

Bromley, G., J. Schaefer, G. Winckler, B. Hall, C. Todd, and K. Rademaker 2009. Relative timing of last glacial maximum and late glacial events in the tropical Andes. Quaternary Science Reviews 28:2514-2526.

Bryan, A. 1991. The fluted-point tradition in the Americas: one of several adaptations to Late Pleistocene American environments. In Clovis Origins and Adaptations, edited by R. Bonnichsen, and K. Turnmire, pp. 15-34. Center for the Study of the First Americans, Oregon State University, Corvallis.

Bush, M. 2002. Distributional change and conservation on the Andean flank: a palaeoecological perspective. Global Ecology and Biogeography 11:463-473.

Castiñeira, C., J. Charlin, M. Cardillo, and J. Baeza 2012. Exploring morphometric variations in fishtail projectile points from Uruguay, Pampa, and Patagonia. In Southbound: Late Pleistocene Peopling of Latin America, edited by L. Miotti, M. Salemme, N. Flegenheimer and T. Goebel, pp. 57-61. Center for the Study of the First Americans, Texas A\&M University, College Station.

Chauchat, C. 1998. Sitios Arqueologicos de la Zona de Cupisnique y Margen Derecha del Valle de Chicama. Patrimonio Arqueológico Zona Norte 4. Instituto Nacional de Cultura la Libertad, Trujillo.

Chauchat, C., J. Pelegrin, C. Gálvez Mora, R. Becerra Urteaga, R. Esquerre Alva, and J. Tixier 2004. Projectile Point Technology and Economy: A Case Study from Paiján, North Coastal Perú. Texas A\&M University Press, College Station.

Chauchat, C., E. Wing, Jean-Paul Lacombe, Perre-Yves Demars, S. Uceda, and C. Deza 2006. Prehistoria de la Costa Norte del Peru. Instituto Francés de Estudios Andinos, Patronato Hauacas del Valle de Moche, Trujillo.

Clapperton, C. 1993. Nature of environmental changes in South America at the last glacial maximum. Palaeogeography, Palaeoclimatology, Palaeoecology 101:189-208.

Craig, A. 1985. CIS-Andean environmental transects: late quaternary ecology of northern and southern Perú. In Andean Ecology and Civilization: An Interdisciplinary Perspective on Andean Ecological Complementarity, edited by S. Masuda, I. Shimada, and C. Morris, pp. 23-44. University of Tokyo Press, Tokyo.

Denton, G., C. Heusser, T. Lowell, P. Moreno, B. Andersen, L. Heusser, C. Schlüchter, and D. Marchant 1999. Interhemispheric linkage of paleoclimate during the last glaciation. Geografiska Annaler 81:107-153.

Dillehay, T. 2000. The Settlement of the Americas: A New Prehistory. Basic Books, New York.

Dillehay, T. 2008. Profiles in Pleistocene History. In Handbook of South American Archaeology, edited by H. Silverman and W. Isbell, pp. 29-43. Springer, New York.

Dillehay, T., D. Bonavia, S. Goodbred Jr., M. Pino, V. Vásquez, and T. Rosales Tham 2012. A late Pleistocene presence at Huaca Prieta, Peru, and early Pacific coastal adaptations. Quaternary Research 77:418-423.
Dillehay, T. and P. Kaulicke. 2013. Tradiciones andinas tempranas. Cultura, tecnología y medioambiente: una introducción. Boletín de Arqueología PUCP 15 (2011):9-16.

Dillehay, T. and J. Rossen 2002. Plant food and its implications for the peopling of the New World. In The First Americans: The Pleistocene Colonization of the New World, edited by N. Jablonski, pp. 237-253. Wattis Symposium Series in Anthropology, Memoirs of the California Academy of Sciences, No. 27. San Francisco.

Dillehay, T, J. Rossen, G. Maggard, K. Stackelbeck, and P. Netherly 2003. Localization and possible social aggregation in the late Pleistocene and early Holocene on the north coast of Perú. Quaternary International 109-110:3-11.

Dillon, M. 1994. Bosques húmedos del norte del Perú. Arnaldoa 2:29-42.

Dillon, M., A. Sagástegui Alva, I. Sánchez Vega, S. Llatas Quiroz, and N. Hensold 1995. Floristic inventory and biogeographic analysis of montane forests in northwest Perú. In Biodiversity and Conservation of Neotropical Montane Forests, edited by S. Churchill, H. Balslev, E. Forero, and J. Luteyn, pp. 251-269. The New York Botanical Garden, New York.

Gálvez Mora, C. 1992. Un estudio de campamentos paijanenses en la quebrada Cuculicote, valle de Chicama. In Estudios de Arqueología Peruana, edited by D. Bonavia, pp. 21-43. FOMCIENCIAS, Lima.

Gálvez Mora, C. 2000. Nuevos datos y problemas sobre el paijanense en el Chicama: aporte para una evaluación de la ocupación temprana en el norte del Perú. Boletín de Arqueología PUCP 3 (1999):41-54. Lima.

Gálvez Mora, C. 2004. El precerámico temprano en la costa norte del Perú. In Desarrollo Arqueológico Costa Norte del Perú, edited by L. Valle Alvarez, pp. 17-28. SIAN, Trujillo.

Gosling, W., M. Bush, J. Hanselman, and A. Chepstow-Lusty 2008. Glacial-Interglacial changes in moisture balance and the impact on vegetation in the southern hemisphere tropical Andes (Bolivia/Peru). Palaeogeography Palaeoclimatology Palaeoecology 259:35-50.

Hajdas, I., G. Bonani, P. Moreno, and D. Ariztegui 2003. Precise radiocarbon dating of late-glacial cooling in mid-latitude South America. Quaternary Research 59:70-78.

Haselton, K., G. Hilley, and M. Strecker 2002. Average Pleistocene climatic patterns in the southern central Andes: controls on mountain glaciation and paleoclimate implications. Journal of Geology 110:211-226.

Hillyer, R., B. Valencia, M. Bush, M. Silman, and M. SteinitzKannan 2009. A 24,700-year paleolimnological history from the Peruvian Andes. Quaternary Research 71:71-82.

Kaulicke, P. 2000. Contribuciones hacia la cronología del Periodo Arcaico en las punas de Junin. Boletin de Arqueología PUCP 3 (1999):307-324.

Kent, S. 1991. The relationship between mobility strategies and site structure. In The Interpretation of Archaeological Spatial Patterning, edited by E. Kroll, and T. Price, pp. 33-59. Plenum Press, New York.

Lavallée, D. 2000. The First South Americans. The University of Utah Press, Salt Lake City. 
Lavallée, D. 2003. The first peopling of the south Pacific American coast during the Pleistocene/Holocene transition-a case study: the prehistoric campsite of Quebrada de los Burros (Tacna, Peru). In Where the South Wind Blows: Ancient Evidence of Paleo South Americans, edited by L. Miotti, M. Salemme, and N. Flegenheimer, pp. 17-20. Center for the Study of the First Americans, Department of Anthropology, Texas A\&M University, College Station.

León Canales, E., J. Alcalde Gonzáles, C. Toledo Gutiérrez, J. Yataco Capcha, and L. Valenzuela Leyva 2004. New possible paleoamerican fish-tail point finds at Laguna Negra, northern Peru. Current Research in the Pleistocene 21:11-13.

Maggard, G. 2010a. Late Pleistocene-Early Holocene Colonization and Regionalization in Northern Perú: Fishtail and Paiján Complexes of the Lower Jequetepeque Valley. Doctoral Dissertation, Department of Anthropology, University of Kentucky, Lexington.

Maggard, G. 2010b. New evidence of fishtail occupation in northern Perú. Current Research in the Pleistocene 27:17-19.

Maggard, G. and T. Dillehay 2011. El Palto phase (13,800-9800 BP). In From Foraging to Farming in the Andes: New Perspectives on Food Production and Social Organization, edited by $\mathrm{T}$. Dillehay, pp. 77-94. Cambridge University Press, Cambridge.

Malpass, M. 1983. The Preceramic Occupations of the Casma Valley, Peru. Doctoral Dissertation, Department of Anthropology, University of Wisconsin, Madison.

Mares, M. 1992. Neotropical mammals and the myth of Amazonian biodiversity. Science 255:976-979.

Mayer-Oakes, W. 1986. Early man projectile and lithic technology in the Ecuadorian sierra. In New Evidence for the Pleistocene Peopling of the New World, edited by A. Bryan, pp. 133-156. Center for the Study of Early Man, University of Maine, Orono.

Mayle, F., Burn, M., Power, M., and D. Urrego. 2009. Vegetation and fire at the lst glacial maximum in tropical South America. In Past Climate Variability in South America and Surrounding Regions from the Last Glacial Maximum to the Holocene, edited by F. Vimeux, F. Sylvestre, and M. Khodri, pp. 89-112. Developments in Paleoenvironmental Research, vol. 14. Springer, Netherlands.

Miotti, L. 2003. Patagonia: a paradox for building images of the first Americans during the Pleistocene/Holocene transition. Quaternary International 109-110:147-173.

Mooney, H., S. Bullock, and E. Medina 1995. Introduction. In Seasonally Dry Tropical Forests, edited by S. Bullock, H. Mooney, and E. Medina, pp. 243-276. Cambridge University Press, Cambridge.

Moseley, M. 1992. The Incas and Their Ancestors. Thames and Hudson, New York.

Nami, H. 2007. Research in the middle Negro River Basin (Uruguay) and the paleoindian occupation of the Southern Cone. Current Anthropology 48:164-174.

Netherly, P. 2011. Pleistocene and Holocene environments from the Zaña to the Chicama valleys 25,000 to 6,000 years ago. In From Foraging to Farming in the Andes: New Perspectives on Food Production and Social Organization, edited by T. Dillehay, pp. 43-76. Cambridge University Press, Cambridge.
ONERN 1976. Mapa ecológico del Perú y guía explicativa. República del Perú, Oficina Nacional de Evaluación de Recursos Naturales. Lima, Perú.

Ossa, P. 1973. A Survey of the Lithic Preceramic Occupation of the Moche Valley, North Coastal Peru: with an Overview of Some Problems in the Study of the Early Human Occupation of West Andean South America. Doctoral Dissertation, Department of Anthropology, Harvard University, Cambridge.

Ossa, P. 1976. A fluted "fishtail" projectile point from La Cumbre, Moche valley, Peru. Nawpa Pacha 13:97-98.

Ossa, P., and M. Moseley 1972. La Cumbre: a preliminary report on research into the early lithic occupation of the Moche valley. Nawpa Pacha 9:1-16.

Piperno, D. 2011. Northern Peruvian early and middle preceramic agriculture in Central and South American contexts. In From Foraging to Farming in the Andes: New Perspectives on Food Production and Social Organization, edited by T. Dillehay, pp. 275-283. Cambridge University Press, Cambridge.

Piperno, D. and T. Dillehay 2008. Starch grains on human teeth reveal early broad crop diet in northern Peru. Proceedings of the National Academy of Sciences 105:19622-19627.

Piperno, D. and D. Pearsall 1998. The Origins of Agriculture in the Lowland Neotropics. Academic Press, New York.

Politis, G. 1991. Fishtail projectile points in the Southern Cone of South America: an overview. In Clovis: Origins and Adaptations, edited by R. Bonnichsen and K. Turnmire, pp. 287302. Center for the Study of the First Americans, Oregon State University, Corvallis.

Pulgar Vidal, J. 1996. Geografia del Perú: las Ocho Regiones Naturales del Perú, la Regionalización y la Sabiduría Ecológica Tradicional (décima edición). Promoción Editorial Inca S.A., Lima.

Richardson III, J. 1973. The preceramic sequence and the Pleistocene and post-Pleistocene climate of northwest Peru. In Variation in Anthropology, edited by D. Lathrap and J. Douglas, pp. 199-211. Illinois Archaeological Survey, Urbana.

Richardson III, J. 1981. Modeling the development of sedentary maritime economies on the coast of Peru: a preliminary statement. Annals of the Carnegie Museum 50:139-150.

Rick, J. and K. Moore. 2000. El precerámico de la punas de Junín: el punto de vista desde Panaulauca. Boletín de Arqueología PUCP 3 (1999):263-296.

Rossen, J. 1991. Ecotones and Low-Risk Intensification: The Middle Preceramic Habitation of Nanchoc, Northern Peru. Doctoral Dissertation, Department of Anthropology, University of Kentucky, Lexington.

Rossen, J. 2011. Las Pircas phase (9800-7800 BP). In From Foraging to Farming in the Andes: New Perspectives on Food Production and Social Organization, edited by T. Dillehay, pp. 95-115. Cambridge University Press, Cambridge.

Sandweiss, D. 2003. Terminal Pleistocene through mid-Holocene archaeological sites as paleoclimatic archives for the Peruvian coast. Palaeogeography, Palaeoclimatology, Palaeoecology 194:23-40.

Sandweiss, D., H. McInnis, R. Burger, A. Cano, B. Ojedo, R. Paredes, M. Sandweiss, and M. Glasscock 1998. Quebrada 
Jaguay: early South American maritime adaptations. Science 281:1830-1832.

Sandweiss, D. and K. Rademaker 2013. El poblamiento del sur Peruano: costa y sierra. Boletín de Arqueología PUCP 15 (2011):274-294.

Stackelbeck, K. 2008. Adaptational Flexibility and Processes of Emerging Complexity: Early to Mid-Holocene Foragers in the Lower Jequetepeque Valley, Northern Perú. Doctoral Dissertation, Department of Anthropology, University of Kentucky, Lexington.

Stackelbeck, K. and T. Dillehay 2011. Tierra Blanca phase (7800-5000 BP). In From Foraging to Farming in the Andes: New Perspectives on Food Production and Social Organization, edited by T. Dillehay, pp. 117-133. Cambridge University Press, Cambridge.

Stothert, K., D. Piperno, and T. Andres 2003. Terminal Pleistocene/ early Holocene human adaptation in coastal Ecuador: the Las Vegas evidence. Quaternary International 109-110:23-43.

Stothert, K. and A. Sánchez Mosquera 2013. Culturas del Pleistoceno final y el Holoceno temprano en el Ecuador. Boletín de Arqueología PUCP 15 (2011):81-119.

Suárez, R. 2003. Paleoindian components of northern Uruguay: new data on early human occupations of the late Pleistocene and early Holocene. In Where the South Winds Blow: Ancient Evidence of Paleo South Americans, edited by L. Miotti, M. Salemme, and N. Flegenheimer, pp. 29-36. Center for the Study of the First Americans, Texas A\&M University Press, College Station.
Suárez, R. 2006. Comments on South American fishtail points: design, reduction sequences, and function. Current Research in the Pleistocene 23:69-72.

Suárez, R. and J. López 2003. Archaeology of the PleistoceneHolocene transition in Uruguay: an overview. Quaternary International 109-110:65-79.

Thouret, J.-C., T. Van der Hammen, B. Salomons, and E. Juvigné 1996. Paleoenvironmental changes and glacial stades of the last 50,000 years in the Cordillera Central, Colombia. Quaternary Research 46:1-18.

Tosi, Jr., J. 1960. Zonas de Vida Natural en el Perú: Memoria Explicativa Sobre el Mapa Ecológico del Perú. Instituto Interamericano de Ciencias Agrícolas, Boletín Tecnico 5. OAS, Zona Andina, Proyecto 39.

Uceda Castillo, S. 1992. La ocupación paijanense en la región de Casma, Perú. Revista de Ciencias Sociales 2:1-78.

Vimeux, F. 2009. Similarites and discrepancies between Andean ice cores over the last deglaciation: climate implications. In Past Climate Variability in South America and Surrounding Regions from the Last Glacial Maximum to the Holocene, edited by F. Vimeux, F. Sylvestre, and M. Khodri, pp. 239255. Developments in Paleoenvironmental Research, vol. 14. Springer, Netherlands.

Weng, C., M. Bush, J. Curtis, A. Kolata, T. Dillehay, and M. Binford 2006. Deglaciation and Holocene climate change in the western Peruvian Andes. Quaternary Research 66(1): 87-96. 